\title{
Student protests succeed in postponing new law
}

For 1986 read 1968 - the year of revolution in French universities which led finally to the resignation of General de Gaulle as President of France. Last week, more than half a million French students and schoolchildren were on the streets to protest against a new law for the universities which, students claim, will tighten up entry requirements, reverse the right of free entry to universities that was won so bitterly by, in many cases, the demonstrators' parents nearly 20 years earlier. Right-wing Prime Minister Jacques Chirac, who dealt with the events in 1968 as a protégé of de Gaulle's prime minister and later president, Georges Pompidou, this time had no stomach for a fight. He told his minister for the universities and research, Alain Devaquet to withdraw the bill for revision.

Resignations do not seem to be in order this time, however. Chirac is not going to see the fall of himself or his government over the issue when the national budget and the economy is his main theme; and the socialist President, François Mitterrand, who might be contending with Chirac in the presidential elections of 1988 and had no involvement in the preparation of the bill, must be laughing up his sleeve. Furthermore, Devaquet, whose law was a compromise between various pressure groups, is said to have many sympathies with the students, and may see the demonstrations as giving weight to his own position. The losers so far in the battle would appear to be 'les emigrés', that group of university staff which was silent, or powerless, during the previous socialist adminis- tration but which now that a right-wing government is in power has been calling for much greater power for the university professors in France, both in the selection of students and over the control of research funds. In the latter case this would have entailed the dismemberment of the French national research council, CNRS, a battle the emigrés recently lost; now, it seems, their battle for more control over their students, 40 per cent of whom leave after one year in university, has also gone against them.

There is thus a good deal of despondency among the rightist camps in French universities this week - if this government cannot help them none can. On the other hand, French natural scientists, who number few of the emigrés among them, are more cheerful. Many deplored yet another attempt to reform the universities, and most thought the new bill's efforts to divide departments into singlesubject faculties retrogressive, likely to reduce interdisciplinary research and to recreate the pre-1968 professional fiefdoms.

Another common complaint of researchers about the new bill was that it threw away the fledgling French $\mathrm{PhD}$, just two years old, to put back the old system of multiple theses and doctorates of various levels which was incompatible with research qualifications outside France and reduced international mobility. The bill before parliament last week, which resulted in the student demonstrations, had been improved in this respect by amendments in the French Senate, but many researchers are still unhappy.

\section{Hermes to win approval soon?}

BrItaIN's space industry was earlier this weeks still awaiting government approval of a proposed multimillion dollar contribution to the European space shuttle project, Hermes. The approval, due last Monday (1 December), is for about 10 per cent, or $\$ 4$ million, for the first phase of the space project. The preparatory phase, which began in the autumn and will take a year to complete, will cost $\$ 40$ million. The complete programme, geared to a launch in 1995-96, will cost $\$ 1,200$ million, of which France and West Germany will provide 39 and 30 per cent, respectively.

But a great deal of research is needed in the preparatory phase to tell how companies with expertise in space technologywill benefit. Nearly 30 submissions on how the technology can be advanced and ex- ploited are with the European Space Agency, which is coordinating the project.

The British National Space Centre, formed about a year ago to coordinate the British space effort, awaits a response from the government to its 15-year plan, which includes the Hermes project. The centre wants an early decision so that preparations can be made for a ministerial meeting of agency members next June.

The Hermes is a space aeroplane to be launched aboard the new European rocket Ariane V, which will be ready for its first flight in about 1994-95. The research on Hermes is expected to inspire applications in other military and civil aviation fields. New types of wings and flight systems would be two possible areas of research.

\section{IMAGE UNAVAILABLE FOR COPYRIGHT REASONS}

\section{Effective yet peaceful protest in Paris.}

ADEMAST, the Association Nationale Pour le Développment et la Maîtrise des Sciences et des Techniques, an association of scientists that grew up after the epochmaking 1982 national colloquium on science and technology in Paris has also strongly criticized the bill, now withdrawn after the protest. In a report published just before last week's demonstrations, ADEMAST admitted deficiencies in the universities but rejected the constant politicization of university reform.

Governments "must work with what exists" rather than attempt in each parliament to recreate the universities anew, said the scientists' associates. And it gave a strong endorsement to the system of multiannual contracts, by which the ministry of education in the previous administration was guaranteeing extra funds to universities.

These funds were available only to establishments which put in place a serious research and training policy to meet local and national needs. These multiannual contracts changed the distribution of university funds from what had been uniform "sprinkling" to real selectivity, the association claimed. But the new bill appeared to be weakening this kind of selection rather than strengthening it

The scientists' association recommends the creation of an agency to distribute university funds selectively. The agency would be indepedent of the ministry, and similar to the British University Grants Committee; but again the new law moved in the opposite direction in the name of autonomy. According to ADEMAST members, French universities are still immature after the revolution of 1968; and the new law would have led to a mere counter-revolution rather than an improvement. Whether any changes at all will now occur is yet to be seen. 